\title{
1. Introduction: active labour market policies, social exclusion, and transitional labour markets
}

\section{Jaap de Koning, Hugh Mosley and Günther Schmid}

This introductory chapter addresses the broader issue of the role active labour market policy (ALMP) can play in combating social exclusion, which is the central policy question addressed in this book. First, we discuss the concept and objectives of active labour market policy as a distinctive form of policy intervention in the labour market. Second, we consider the meaning and measures of 'social exclusion' and the extent to which it is affected by labour market outcomes, especially long-term unemployment. Finally, we discuss the concept of transitional labour markets, its diagnosis of the changing nature of modern labour markets, and its implications for active labour market policies.

\section{ACTIVE LABOUR MARKET POLICY}

Active labour market policies are a subset of labour market and employment policies which are aimed primarily at either preventing unemployment among at-risk individuals; or, if these individuals do become unemployed, at promoting their reintegration into the labour market and their career advancement. The International Labour Organization (ILO), for example, defines ALMP as 'purposive, selective interventions by the government in the pursuit of efficiency and/or equity objectives, acting indirectly or directly to provide work to, or increase the employability of people with certain disadvantages in the labour market'.

It should be noted that active labour market policies represent only one of several types of intervention designed to affect supply or demand in the labour market. Other labour market policies not examined here are also very important, including 'passive' income maintenance programmes, measures aimed at reducing the existing supply of labour (for example, early retire- 
ment, reductions in working time), regulatory interventions in the labour market (for example, employment protection regulations, equal opportunity regulations), as well as wage policies.

In recent years, European countries have experienced very high levels of unemployment and long-term unemployment and expenditure for active measures has been substantial. Among the countries studied in this book (France, Germany, the Netherlands, Spain and Sweden), unemployment was lowest in the Netherlands (5.2 per cent) and highest in Spain (20 per cent). In the EU as a whole, 10.6 per cent of the labour force was unemployed in 1997, and about 50 per cent of unemployed people had been out of work for more than one

Table 1.1 Active labour market policies and unemployment, France, Germany, the Netherlands, Spain and Sweden

\begin{tabular}{|c|c|c|c|c|c|}
\hline & & $\begin{array}{l}\text { Standardized } \\
\text { unemployment } \\
\text { rate }\end{array}$ & $\begin{array}{l}\text { Long-term } \\
\text { unemployment } \\
\qquad(>12 \mathrm{~m})^{\mathrm{a}}\end{array}$ & $\begin{array}{c}\text { ALMP } \\
\text { expenditure } \\
(\% \text { GDP })\end{array}$ & $\begin{array}{c}\text { ALMP } \\
\text { participants } \\
\text { (\% labour } \\
\text { force })\end{array}$ \\
\hline \multirow[t]{3}{*}{ France } & 1997 & 12.4 & 41.2 & $1.32^{\mathrm{b}}$ & $11.3^{\mathrm{c}}$ \\
\hline & 1990 & 9.0 & 38.0 & 0.8 & $7.6^{\mathrm{d}}$ \\
\hline & 1985 & 10.2 & 46.8 & 0.7 & - \\
\hline \multirow[t]{3}{*}{ Germany ${ }^{\mathrm{e}}$} & 1997 & 9.7 & $47.8^{f}$ & 1.3 & 3.6 \\
\hline & 1990 & 4.8 & 46.8 & 1.0 & $3.4^{\mathrm{g}}$ \\
\hline & 1985 & 7.2 & 47.9 & 0.8 & - \\
\hline \multirow[t]{3}{*}{ Netherlands } & 1997 & 5.2 & 49.1 & 1.5 & 14.2 \\
\hline & 1990 & 6.2 & 49.3 & 1.1 & 2.9 \\
\hline & 1985 & 10.6 & 58.7 & 1.1 & - \\
\hline \multirow[t]{3}{*}{ Spain } & 1997 & 20.8 & 55.5 & 0.5 & 2.9 \\
\hline & 1990 & 16.2 & 54.0 & 0.8 & 7.2 \\
\hline & 1985 & 21.4 & 56.8 & 0.3 & 4.3 \\
\hline \multirow[t]{3}{*}{ Sweden } & 1997 & 10.2 & 29.6 & 2.1 & 13.5 \\
\hline & 1990 & 1.8 & 4.7 & 2.1 & 3.6 \\
\hline & 1985 & 2.8 & 11.4 & 2.1 & - \\
\hline \multirow[t]{2}{*}{$\mathrm{EU}^{\mathrm{h}}$} & 1997 & 10.7 & 47.4 & - & - \\
\hline & 1990 & - & 48.6 & - & - \\
\hline
\end{tabular}

Notes:

a Persons unemployed more than 12 months as percentage of all registered unemployed.

b 1996.

c 1995.

d 1989.

e 1980 and 1990 only western Germany.

f 1996.

g 1989.

h EU unemployment rates for 1997 are estimates.

Source: OECD Employment Outlook, various years. 
year. Expenditure for ALMP ranged from 0.5 per cent of GDP in Spain to 2.2 per cent in Sweden in 1997 and a large percentage of the unemployed participate in active measures in all five countries (Table 1.1).

The role of active labour market policy has undergone a fundamental transformation. Active labour market policy as a set of instruments for direct state intervention in the labour market has a long history. It developed gradually during this century. Public employment offices were established in most countries around the turn of the century and in some countries even earlier. Specific measures such as job-creation schemes were introduced on a large scale during the great depression in the 1930s. Training for the unemployed was applied on a wide scale after World War II, when there was a shortage of skilled labour. However, active labour market policy as an integral part of socio-economic policy as a whole was first conceived and applied in Sweden and widely disseminated by the OECD in the 1960s (OECD, 1964). At that time, ALMP was considered to be an integral part of a broader economic strategy of facilitating geographic and occupational mobility, thus accelerating structural change. It was also seen as an alternative to exclusive reliance on macroeconomic policies in economies near full employment (RehnMeidner model). Today, however, in an era of slower growth and persistently high levels of mass unemployment, the immediate goal is no longer full employment. Instead, European policy-makers in the 1990s view ALMP primarily as a means of ameliorating unemployment - especially long-term unemployment - and of combating social exclusion. ${ }^{1}$

During the past decade increasing doubts about the effectiveness of government intervention in general have led to greater emphasis on the role of the market mechanism in dealing with socio-economic problems. This has also left its mark on labour market policy. In many countries the state monopoly in job brokering has been abolished (see de Koning, Denys and Walwei, 1999), the legal basis for private job placement agencies has been improved, and some public employment service activities are being privatized. There have also been reforms in social protection systems with the goal of enhancing the incentives for the unemployed to accept jobs and for employers to increase employment. However, there will remain a need for active policies for two main reasons. First of all the labour market suffers from a number of imperfections such as imperfect information, wage rigidities and discrimination. ${ }^{2}$ Moreover, unemployment is an inevitable by-product of market economies, and, therefore, some level of public intervention will always be needed. Although there are also alternative policies, for example, equal opportunity regulations, active policies seem to be indispensable, and these programmes have in fact been expanded in most countries over the past decade.

It is important to note that ALMP consists of different types of measures with somewhat different purposes. ${ }^{3}$ Some measures, such as work-experience 
schemes or other subsidized labour schemes, are designed to help disadvantaged groups for whom work experience is the first step towards reintegration into the labour market. Therefore, their principal aim is to promote equal opportunity. It could also be argued that, by enhancing the employability of unemployed people, labour market efficiency also improves. In addition, training can be used as a means of increasing the employability of disadvantaged groups. Moreover, this instrument helps reduce mismatch between labour demand and labour supply. While job brokering activities are primarily intended to increase the transparency of the labour market and are usually available to all categories of job seekers and employers, they may, in certain cases, be aimed at specific groups (for example, by attempting to achieve equal representation of target groups in the placement results). For disadvantaged groups, subsidized labour, training and placement activities are increasingly combined in pathways to labour market integration. Thus, all three types of ALMP measures (subsidized labour, training and job placement) are used to promote the reintegration of disadvantaged persons. The same is true for the general information function of ALMP (that is, providing information about job seekers to employers, and about job vacancies to those looking for work). Combating long-term unemployment is given high priority by most, if not all, countries.

Is ALMP really effective in practice, either in reducing the level of unemployment or the incidence of long-term unemployment? This is the central question in the evaluation literature on ALMP, which is addressed in the substantive chapters in this volume. We do not wish to anticipate these findings here; nor is this the place for a detailed discussion of the evaluation literature on ALMP (see Schmid et al., 1996). Nevertheless, some preliminary remarks on this issue are appropriate.

First, ALMP could redistribute job opportunities so that fewer people become long-term unemployed. But when total employment and total labour supply are given, this would imply distributing the unemployment burden among more people. ${ }^{4}$ Clearly, an increase in total employment as a result of ALMP would be preferable to a redistribution of unemployment among a greater number of people. It is, however, not at all obvious that ALMP can have a direct effect on total employment.

In economic theory, a positive effect on total employment will emerge directly only insofar as friction between labour demand and labour supply is reduced as a result of ALMP. Yet, as we have experienced in the recent past, excess supply on the labour market tends to be so great that vacancies are usually filled very easily. Thus, ALMP will hardly affect total employment directly. The only exception to this general rule is subsidized job creation. But even in that case, the effect on total employment is uncertain owing to possible displacement and substitution effects. 
While it is doubtful and perhaps even improbable that ALMP can have a positive effect on total employment in the short term, it may do so in the long term. Firms are often reluctant to recruit certain categories of unemployed workers, such as long-term unemployed people. When a person is no longer receiving job offers, he or she is virtually excluded from the labour market. But when ALMP succeeds in reintegrating this category of unemployed persons, the effective labour supply increases. This may have a positive effect on employment in two separate ways (Bellman and Jackman, 1996a): wages will be affected negatively, which may eventually have a positive effect on employment, and recruitment will be eased. Moreover, Broersma et al. (1997) argue that the wage effect underestimates the total effect of an increased labour supply on employment. First, an increased labour supply will ease the filling of vacancies. Furthermore, supply may become available for types of work for which previously no one was available (latent vacancies or discouraged labour demand). ${ }^{5}$ Therefore reintegrating the long-term unemployed and preventing long-term unemployment is certainly worth while. These studies provide circumstantial evidence regarding the aggregate impact of ALMP.

Finally, although the potential impact of ALMP on total employment appears to be limited if labour demand and supply are given, supply and demand on the labour market are in fact complex institutional constructs that can be steered to a certain extent by policy interventions at the microlevel, including ALMP. Thus even if the total volume of employment were given, there is a broad range of conceivable constellations of labour supply and demand and the level of unemployment is not univocally determined by total employment. The concept of transitional labour markets offers an alternative rationale for ALMP which aims to leverage the impact of available employment on unemployment through institutional arrangements to facilitate reduced working hours, individual transitions in working time, and transitions between paid work and other socially useful activities (see section 3 below).

So far, most research regarding the impact of ALMP has been of the type in which micro-data is used to estimate the effect of individual measures on the income and the job chances of ALMP participants. However, the results obtained from micro-studies may not give an adequate picture of the overall impact of ALMP as a whole on the labour market. Aggregate impact analyses are needed to deal with the consequences of displacement and other aggregate effects, which lead to a discrepancy between micro- and macro-outcomes. However, the number of aggregate impact studies, relating aggregate ALMP indicators directly to aggregate employment and unemployment indicators, is relatively small. Furthermore, the attempts made failed to produce convincing results. ${ }^{6}$ The ALMP evaluations for France, Germany, the Netherlands, Spain and Sweden reported in this volume address this issue in a methodo- 
logically innovative way on the basis of regional-level aggregate impact analyses.

It is, moreover, highly likely that the results of ALMP depend greatly on the way it is organized and implemented. This aspect of ALMP is usually neglected in both micro- and macro-studies on the impact of ALMP. ${ }^{7}$

\section{SOCIAL EXCLUSION, POVERTY AND THE LABOUR MARKET}

ALMP can play a role in preventing social exclusion by reducing unemployment, especially long-term employment. After discussing the variety of meanings of 'social exclusion', we argue that labour market outcomes are in any case an important determinant. This point is illustrated by selective data available on unemployment as a cause of poverty.

Silver (1998) draws attention to three different features of 'social exclusion'. First, social exclusion is multidimensional: it is not reducible to monetary terms but combines economic and social problems, material and symbolic relations, distributional conflicts and identity politics, class and status orders, social rights and human rights. Second, social exclusion refers to a dynamic process: material want and/or lack of gainful employment can set in motion an individual or group tendency towards social disengagement, disaffiliation, disqualification, or isolation. Third, social rights institutionalized as entitlements to income transfers from insurance or assistance programmes may foster stigmatization, passivity, rejection and feelings of powerlessness. ${ }^{8}$

Kronauer (1997) identifies five principal uses of the term which reflect different national policy discourses. Social exclusion sometimes refers primarily to the special problem situation of an urban ethnic 'underclass', especially in the USA and, to a lesser extent, in the UK, where social exclusion often takes the form of urban ghettos. In France it is used primarily to refer to the problem of unemployed and marginally employed youth, particularly second-generation immigrant youth. The concept is frequently used to refer to the long-term unemployed, especially older workers who have been displaced by structural change from their previous employment and career path. Other authors associate social exclusion with marginal groups at the periphery of society who, for a variety of reasons, are homeless or poor. In an even more restricted definition, social exclusion is applied solely to illegal immigrants.

The heterogeneity of the groups that have, at various times, been labelled 'socially excluded' illustrates the difficulty of defining the term. On the one hand, social exclusion can be defined more restrictively as a situation in 
which people cannot satisfy their basic needs over a long period of time. This definition is closely related to poverty, which is usually defined in terms of the resources available to a household. On the other hand, social exclusion can be defined more broadly. Although poverty is a core indicator, the emphasis on 'social exclusion' in the European policy discourse since the late 1980s represents a shift away from the use of income measures. Thus, the EU Observatory on National Policies to Combat Social Exclusion has consistently defined social exclusion in terms of social rights (for example, to employment, housing, health care; see Huster, 1997). As Room (1995) points out, it is the word 'social' that makes the difference. While they may not suffer poverty and physical deprivation, being out of work for a very long time may deprive people of social contacts and the personal fulfilment attained from working. In addition, there is evidence that social isolation further reduces job chances because people frequently draw information and motivation for their job search from social contacts and social networks (Anxo and Storrie, 1999).

These two meanings of social exclusion overlap only partially: while some people who are not poor may be socially excluded (for example, the aged or the long-term unemployed in households with sufficient income), people living in poor households may not, in fact, be socially excluded. Indeed, absolute poverty is rare in Europe, where poverty is usually defined on the basis of relative income. Thus, some people classified as poor according to statistical standards may be satisfactorily integrated into social and economic life. ${ }^{9}$

Labour market outcomes, especially long-term employment, are clearly an important cause of social exclusion in the narrow sense of insufficient income and poverty, and in the broader sense of inadequate social integration and lack of self-fulfilment. ${ }^{10}$ While no recent systematic data are available at the European level, earlier studies show that unemployment is a major cause of poverty and social exclusion. In the late 1980s in France, 34.8 per cent of the households with an unemployed head of household were classified as poor; in Spain, it was 29.3 per cent, in Portugal 47.5 per cent, in Italy 35.7 per cent, in Greece 24.5 per cent, in Ireland 43.6 per cent, in Belgium 28.3 per cent and in Luxembourg 44.1 per cent (Ramprakash, 1994). Although the methodological problems of international comparisons of poverty are considerable (defined here in terms of the weighted average expenditure for all households), it is evident that poor households tend to be affected by unemployment. This conclusion is also confirmed by more recent national data on reasons for receipt of means-tested social assistance benefits. In Germany in 1997, 39.4 per cent of social assistance beneficiaries over the age of 15 were registered as unemployed, and 24.8 per cent as 'long' long-term unemployed (more than 1 year). ${ }^{11}$ 
Even short-term unemployment can be a problem when the same person experiences short spells of unemployment frequently, and becomes trapped in the segment of the labour market where low wages, temporary contracts and bad working conditions prevail. Recent German research has also identified 'dynamic unemployment', that is, frequently recurring spells of unemployment that affect more and more persons for longer and longer periods - as a new structural feature of unemployment (Mutz, 1995). In a recent Dutch study, de Koning, van Nes and van der Veen (1999) concluded that, while single spells of long-term unemployment account for most lifecycle unemployment, the importance of shorter spells is growing owing to the increasing share of flexible labour in total labour volume. ${ }^{12}$

Marginalization or exclusion from the labour market does not always result in social exclusion. People may have permanent but low-paid employment that provides an acceptable living standard. Moreover, in all societies labour market outcomes are mediated and cushioned by the intervening welfare state, as well as by societal and, in particular, familial safety nets. Thus, even the same level of unemployment or long-term unemployment will have a very different impact in terms of social exclusion depending on the institutional and societal context. Finally, there are other meaningful activities in addition to paid employment which can be a source of social integration and individual fulfilment. Nevertheless, the prevention of long-term and recurrent unemployment would be a major contribution towards combating poverty and social exclusion. From the previous discussion we can conclude that active policies can be an important tool in combating social exclusion by reducing unemployment and, in particular, long-term unemployment.

\section{TRANSITIONAL LABOUR MARKETS AND ACTIVE POLICIES}

The labour market has changed considerably since the mid-1970s. Unemployment rates have grown to levels unprecedented in postwar history, and it is highly unlikely that in the near future unemployment will return to the levels of the 1960s. Even in countries with relatively low official unemployment rates, such as the Netherlands, 'true' unemployment is still high when hidden unemployment is taken into account. The current prolonged period of high unemployment has cast serious doubts on the feasibility of full employment as it was traditionally understood (Schmid, 1995).

The level of unemployment is not the only thing that has changed: the underlying dynamics of the labour market are now quite different from the patterns of the past. Until recently, most employees stayed with the same employer during their entire working lives, and very few people switched 
occupations. Yet increasingly, this pattern is disappearing under the influence of what is sometimes referred to as economic turbulence. Today, things change so quickly that people are less sure of finding and keeping a job. Initial education or training is no longer sufficient to remain employable during working life; continuous training is needed to keep up with the developments in many professions. In addition, because the life cycle of companies tends to be shorter today than it once was, employees may lose their jobs when companies go bankrupt. Finally, occupations may disappear completely as a result of technological progress.

Tables 1.2 and 1.3 show clearly that, in both the Netherlands and Germany, younger generations have been confronted with unemployment to a greater extent than the older generations. The difference is particularly significant for short-term unemployment and unemployment of intermediate duration, although the results may suffer from under-reporting by older generations. ${ }^{13}$ Thus the percentage of respondents who report never having been unemployed is markedly lower for the two youngest cohorts (58 per cent and 66 per cent respectively for the Netherlands; 80 per cent and 73 per cent for Germany), despite the shorter duration of their labour force participation. In Germany, it is interesting to observe that women in the oldest cohort were less affected by unemployment than men, whereas women in the younger generations have almost the same risk of experiencing short-term unemployment and the same or a slightly higher risk of long-term unemployment (see Tables 1.2 and 1.3).

There is not only not enough full-time employment for everyone, the available employment is less stable than it was in the past. As a result, the probability of an individual experiencing one or more periods of unemployment during his or her working life has increased considerably. Once people

Table 1.2 Lifetime unemployment according to year of birth, the Netherlands, 1995 (in percentage of cohort)

\begin{tabular}{lrrrr}
\hline $\begin{array}{l}\text { Number of } \\
\text { years in } \\
\text { unemployment }\end{array}$ & $1930-38$ & $1940-49$ & $1950-59$ & $1960-69$ \\
\hline Never been unemployed & 86 & 79 & 66 & 58 \\
0-1 year & 6 & 11 & 18 & 26 \\
1-4 year & 5 & 8 & 12 & 13 \\
5 years or more & 3 & 3 & 4 & 4 \\
Total & 100 & 100 & 100 & 100 \\
\hline
\end{tabular}

Source: Statistics Netherlands. 
Table 1.3 Lifetime unemployment according to year of birth, Germany 1981-3, 1989 (in percentage of cohort)

\begin{tabular}{lcccc}
\hline $\begin{array}{l}\text { Number of } \\
\text { years in } \\
\text { unemployment }\end{array}$ & $1930-31$ & $1940-41 / 1949$ & $1950-51 / 1954-56 / 1959$ & $1960-61$ \\
\hline $\begin{array}{l}\text { Never been } \\
\text { unemployed }\end{array}$ & $93(96)$ & $93(95)$ & $80(81)$ & $73(74)$ \\
$\begin{array}{l}\text {-1 year } \\
1-4 \text { year }\end{array}$ & $4(3)$ & $6(3)$ & $12(11)$ & $18(16)$ \\
5 years or more & 0 & $1(1)$ & $6(6)$ & $8(8)$ \\
$\begin{array}{l}\text { Total } \\
(\mathrm{N})\end{array}$ & $100(100)$ & $100(100)$ & $100(100)$ & $100(100)$ \\
& $(489)(243)$ & $(717)(352)$ & $(1788)(857)$ & $(641)(321)$ \\
\hline
\end{tabular}

Note: Figures in parentheses represent women. Figures may not add up to 100 per cent because of rounding; $0=>0.5$ per cent. ${ }^{14}$

Source: German Life History Study, 1981-83 and 1989, Max-Planck Institute for Human Development, Berlin.

have become unemployed, they risk becoming long-term unemployed. This is particularly true for the low-skilled, for persons of foreign origin, and, to some extent, for women. ${ }^{15}$ As was noted in the previous section, long-term unemployment often entails social exclusion.

Active labour market policy cannot alter the higher level of risk in today's labour markets. This increased insecurity is inherent in a number of fundamental changes in the way the economy works, such as changes in consumer preferences, technological development and the globalization of the economy. But it might be possible to prevent long-term unemployment, or at least to minimize its incidence. Increased insecurity for individuals who face a higher risk of encountering unemployment, recurring unemployment, or long-term unemployment during their working lives owing to the changing nature of labour markets implies a much greater need for active policies that maintain labour force attachment and bridge transitions to re-employment.

The traditional forms of active labour market policy are no longer suitable for dealing with the new trends towards social exclusion and the need for reorganizing work. Traditional active labour market policy was, for example, defined as 'manpower' policy, while viewing women as part of a marginal or peripheral labour force. Today, however, the goal of active or proactive labour market policy is equal opportunity for both sexes in the labour market. Moreover, while conventional active labour market policy was closely connected with the idea of coping with structural imbalances on the labour market by regional mobility and of coping with cyclical imbalances by tem- 
porary public relief work; new active labour market policy must adjust to the new features of structural change, notably globalization of production or markets and new technologies on the demand side, and individualization, social differentiation or new migration streams on the supply side. Which strategies, policies or policy mixes are suitable to solve the problems arising from these changes is currently being debated.

The concept of transitional labour markets (TLM) hypothesizes that the borderlines between gainful dependent labour market work and other productive activities are becoming more and more blurred. The 'standard labour contract' - that is, full-time, continuous employment - is eroding, but we do not yet know which new standards will develop to replace it. Evidence suggests, however, that people are increasingly moving between different labour market statuses; for example between different working-time regimes, between unemployment and employment, between education or training and employment, between unpaid family work and gainful labour market work, and between work and retirement. Some of these transitions are critical in the sense that they may lead to downward spirals of job careers, ending finally in long-term unemployment, poverty, discouraged withdrawal from the labour market, or violent protest. New kinds of institutional arrangements are necessary to prevent transitions from becoming paths to social exclusion and to transform them into paths of opportunity. 'Making transitions pay' (Schmid, 1998) requires the creation of institutions which provide one or more of the following: work organizations which enable people to combine labour market work with other productive activities; income arrangements which combine wages or salaries with other income sources such as transfers, equity shares or savings; entitlements or social rights which allow choices to be made between different employment statuses according to shifting preferences and circumstances; and policy provisions which allow the multiple use of social insurance funds, especially the use of income maintenance programmes (for example, unemployment insurance) for financing measures that enhance employability. It may, however, be necessary in a transitional labour market to accompany the introduction of these various forms of empowerment - especially the creation of new social rights - with the demand for the fulfilment of certain obligations, such as participation in professional further training.

Transitional labour markets are in particular forms of career flexibility in working time through institutional bridges between full-time employment and periods of reduced working time and career breaks for training, family or personal reasons. This paradigm is most directly applicable to employed persons with relatively secure positions in internal labour markets. The facilitation of such transitions through public regulations and programmes, collective agreements, and changes in the personnel policies of enterprises, however, also improves employment opportunities for the unemployed. In some cases 
programmes to promote transitional labour markets for the employed are explicitly tied to the hiring of a replacement from among the unemployed; for example, the Scandinavian leave schemes. ${ }^{16}$ Even where there is no such stipulation, the need to replace 'insiders' who temporarily interrupt their careers or reduce their working time creates additional employment opportunities for 'outsiders'; that is, the unemployed and new entrants.

There are two mechanisms by which these institutional arrangements may improve the chances of the unemployed: 1) a turnover effect, and 2) a labour supply (work-sharing) effect. The first of these suggests that increased turnover between relatively secure positions in internal labour markets and the unemployed reduces the average duration of unemployment. The second proposes that unemployment may not just be redistributed, but could actually be reduced through voluntary reductions in working time or temporary withdrawal from the labour market induced by transitional labour markets. The actual impact of transitional labour markets on unemployment depends on a multitude of factors which must be investigated empirically: to what extent do reductions in the working time of individual employees actually result in replacement hires rather than being offset, for example, by productivity increases or increases in the working time of existing employees? Moreover, are the additional job opportunities taken by the unemployed or by new entrants?

Active measures for the unemployed (for example, training, job creation, wage subsidies) also promote transitions - in this case from unemployment to employment - but are, in fact, qualitatively different from the transitional schemes for the employed. Whereas the latter are relatively secure temporary bridges between employment and other types of activity, the former enhance employability at best, but are not a ticket to regular employment. What is the added value in viewing ALMP for the unemployed from a transitional labour market perspective? One implication is that the priority goal is clearly placement in regular employment. Job-creation programmes should be temporary or counter-cyclical, and the terms and conditions of employment should be less attractive than regular employment. Measures should be as close to the regular labour market as possible (for example, enterprise-based) rather than in a special publicly supported labour market segment (for example, 'zweiter Arbeitsmarkt'). While the introduction of such measures may increase the likelihood of displacement of employment in competing firms or substitution of programme participants for other employees, this is an acceptable risk if the overall effect is to reduce the average duration of unemployment. Indeed, from the point of view of the unemployed, perhaps the most important implication of a TLM approach to ALMP is that displacement and substitution effects become more tolerable if they increase employment opportunities for the long-term unemployed and other problem groups and thus combat 
social exclusion. Increased turbulence in labour markets due to the pace of technological development and intensified competition means that individuals will be increasingly confronted with more or less involuntary transitions in their working lives. Therefore, the need for job search assistance and training for people in danger of losing their job or becoming obsolete in terms of their human capital will increase. Preferably, unemployment should be avoided and as far as government policy is needed for this type of measure, one could speak about preventive ALMP for employed persons. But it is possible that, despite an increased effort to prevent unemployment, employment-to-unemployment transitions will occur more frequently than in the past. That would also mean that more has to be done to re-employ displaced workers and to prevent long-term unemployment.

At the same time we should not be overly pessimistic about the possibility of reducing the overall unemployment rate. Countries such as Denmark, Ireland and the Netherlands have shown that policies such as wage moderation, promotion of training, deregulation and social security reforms can have a substantial impact on unemployment, even taking hidden unemployment into account. Nevertheless, the remaining level of unemployment will still be too high from a social point of view, and active policies will be needed to distribute the unemployment burden over more people and to promote 'good' transitions. This will be easier to achieve and to finance insofar as mass unemployment can be mitigated.

\section{NOTES}

1. This shift in emphasis does not mean that ALMP is no longer concerned with skill shortages, which can occur even in countries experiencing high levels of unemployment. Moreover, firms have increasingly had problems in filling vacancies in countries like the Netherlands and Denmark in which unemployment has declined markedly.

2. See de Koning (1993b) for an in-depth discussion.

3. The OECD distinguishes the following types of active labour market policy: 1) public employment services (and administration), 2) labour market training for unemployed and employed adults, 3) youth measures, 4) subsidized employed (for example, wage subsidies and direct job creation) and 5) measures for the disabled.

4. Assuming that not the same persons are experiencing more unemployment spells as a result of the policy intervention.

5. According to their results the total labour supply elasticity of employment is almost equal to 1 .

6. See Chapter 2 of this volume for a review of the literature.

7. See Chapter 7 in this volume on the importance of implementation.

8. See Leisering (1997) for a recent discussion of 'social exclusion' in the German sociological tradition. For Georg Simmel poverty as a social category is defined not by individual need but by the status of being dependent on public assistance, which in the earlynineteenth century entailed loss of civil and political rights.

9. Berghman (1995) refers to a Dutch study by Muffels et al. (1992) according to which only 30 per cent of the poor are also socially excluded (or 'deprived'). Moreover, according to 
this study, 8 per cent of the non-poor are socially excluded. The conclusion is that both the poor and the socially excluded amount to 10 per cent of the population, but that the two are only partly overlapping. Their definition of poverty is based on the official subsistence norm, while their social exclusion concept is based on individuals' perception of their own situation.

10. In general the probability of leaving unemployment declines with increasing duration. Thus Ludwig-Mayerhofer (1996), a recent German study based on longitudinal data, concludes that the probability of moving from unemployment to full-time employment is strongly negatively related to the cumulative duration of previous spells of unemployment (but actually positively related to the number of spells!). The extent to which long-term unemployment is explained by personal characteristics or 'path dependence', that is, the impact of unemployment itself is controversial and will not be discussed here (Kiefer, 1988).

11. Forty per cent of all households (Bedarfsgemeinschaften) on social assistance have at least one member who is registered unemployed; calculated from Statistisches Bundesamt (1997).

12. A striking result of their analysis is that also from a longitudinal point of view unemployment is highly concentrated among a relatively small group of people. If one would follow a cohort of individuals over their working life, the 10 per cent experiencing unemployment most during their working life account for 50 per cent of the sum total of all unemployment periods experienced by all the people in the cohort during their active lives. In other words, it is more or less the same group of people that is unemployed all of the time.

13. Since most people will have been out of work for a short period, short spells of unemployment may be underestimated and especially older persons may have forgotten.

14. We thank Prof. Karl Ulrich Mayer (Director at the Max-Planck-Institute for Educational Research in Berlin), Heike Solga and Monika Albin who kindly provided these results from the German Life History Study. They note that these figures are based on subjective and retrospective reporting by respondents, which is subject to error. This is especially the case for older cohorts, who may no longer accurately recall earlier experiences of unemployment. Furthermore, the data are derived from two different studies conducted at different times and are thus not strictly comparable. The data in columns 1 and 2 refer to unemployment experiences only until the beginning of the 1980s whereas the data for the younger cohorts (columns 3 and 4) cover the period until the end of the 1980s. Moreover, only persons who have ever been employed were asked about spells of unemployment, which means that students and recent university graduates are not included in the youngest cohort.

15. The share of long-term unemployed for men in EU(15) was 47.4 per cent in 1997 , for women 50.6 per cent (Commission 1998, p. 149).

16. For Denmark see Madsen (1998) and Schmid and Schömann (1999).

\section{REFERENCES}

Anxo, D. and D. Storrie (1999), 'Employability, jobsearch, employer recruitment strategies, social networks and social exclusion', in B. Gazier (ed.), Employability: Concepts and Policies, Berlin: I.A.S.

Bellmann, L. and R. Jackman (1996a), 'Aggregate impact analysis', in G. Schmid, J. O'Reilly and K. Schömann (eds), International Handbook of Labour Market Policy and Evaluation, Cheltenham: Edward Elgar, pp. 143-62.

Bellman, L. and R. Jackman (1996b), 'The Impact of labour market policy on wages, employment and labour market mismatch', in G. Schmid, J. O'Reilly and K. Schömann (eds), International Handbook of Labour Market Policy and Evaluation, Cheltenham: Edward Elgar, pp. 725-46. 
Berghman, J. (1995), 'Social exclusion in Europe: policy context and analytical framework', in G. Groom (ed.), Beyond the Threshold. The Measurement and Analysis of Social Exclusion, Bristol: Policy Press.

Broersma, L., J. Koeman and C.N. Teulings (1997), Arbeidsaanbod en werkgelegenheid ('labour supply and employment'), Economisch Statistische Berichten 82-4127, pp. 836-40.

European Commission (1998), Employment in Europe, Luxembourg: Office of Official Publications.

Huster, E.U. (1997), 'Armut in Europa - ausgewählte Ergebnisse dese Armutsobservatoriums der Europäischen Union', in I. Becker and R. Hauser (eds), Einkommensverteilung und Armut. Deutschland auf dem Weg zur VierfünftelGesellschaft?, Frankfurt/M., New York: Campus Verlag.

Kiefer, N.M. (1988), 'Economic duration data and hazard functions', Journal of Economic Literature, XXVI, 646-79.

Koning, J. de (1993a), 'Measuring the placement effects of two wage-subsidy schemes for the long-term unemployed', Empirical Economics, 8.

Koning, J. de (1993b), 'The Dutch experience', in K. Jensen and P.K. Madsen (eds), Measuring Labour Market Measures, Copenhagen: Ministry of Labour.

Koning, J. de, P.J. van Nes and C. van der Veen (1999), The Distribution of Life-time Unemployment: A Simulation Approach, Rotterdam: NEI.

Koning, J. de, J. Denys and U. Walwei (1999), 'Deregulation in placement services: a comparative study for eight EU countries', published by the European Commission.

Kronauer, M. (1997), 'Soziale Ausgrenzung' und 'Underclass': Über neue Formen der gesellschaftlichen Spaltung', Leviathan, 25 (1), 28-49.

Leisering, L. (1997), 'Soziale Ausgrenzung' - Zur handlungsthoretischen Fundierung eines aktuellen sozialpolitischen Diskurses, in K.S. Rehberg (ed.), Differenz und Integration. Die Zukunft moderner Gesellschaften, Band II, pp. 1039-53.

Ludwig-Mayerhofer, W. (1996), 'Was heißt, und gibt es kumulative Arbeitslosigkeit? Untersuchungen zu Arbeitslosigkeitsverläufen über 10 Jahre', in W. Zapf, J. Schupp and R. Habich (eds) Lebenslagen im Wandel: Sozialberichterstattung im Längsschnitt, Frankfurt/M., New York: Campus Verlag, pp. 211-39.

Madsen, P.K. (1998), 'A transitional labour market: the Danish paid leave arrangements', in European Academy of the Urban Environment, New Institutional Arrangements in the Labour Market, Berlin: Publications of European Academy of the Urban Environment, pp. 68-73.

Muffels, R., J. Berghman and H. Dirven (1992), 'A multi-method approach to monitor the evolution of poverty', Journal of European Social Policy, 2, 193-213.

Mutz, G., W. Ludwig-Mayerhofer and E.J. Koenen (1995), 'Diskontinuierliche Erwerbsverläufe. Analysen zur postindustriellen Arbeitslosigkeit, Biographie und Gesellschaft', Bd. 21, Opladen: Leske + Budrich.

OECD (1964), Recommendations on an Active Manpower Policy, Paris: Manpower and Social Affairs Committee.

OECD (various years), Economic Outlook, Paris.

Ramprakash, D. (1994) 'Poverty in the countries of the European Community. Synthesis of Eurostat's Statistical Research in Poverty', Journal of European Social Policy, 4 (2), 117-28.

Room, G. (ed.) (1995), Beyond the Threshold. The Measurement and Analysis of Social Exclusion, Bristol: Policy Press.

Schmid, G. (1995), 'Is full employment still possible? Transitional labour markets as 
a new strategy of labour market policy', Economic and Industrial Policy, 16, 42956.

Schmid G. (1998), Transitional Labour Markets: A New European Employment Strategy, WZB Discussion Paper FS I 98-206, Berlin: WZB.

Schmid, G., J. O'Reilly and K. Schömann (eds) (1996), International Handbook of Labour Market Policy and Evaluation, Cheltenham: Edward Elgar.

Schmid, G. and K. Schömann (eds) (1999), Von Dänemark lernen - Learning from Denmark, WZB Discussion Paper FS I 99-201, Berlin: WZB.

Silver, H. (1998), 'Policies to reinforce social cohesion in Europe', in J.B. Figueiredo and A. de Haan (eds), Social Exclusion: An ILO Perspective, Geneva: International Institute for Labour Studies, Research Series 111, pp. 38-73.

Statistisches Bundesamt (1997), Fachserie 13: Sozialleistungen, Reihe 2: Sozialhilfe, Wiesbaden: Metzler-Poeschel. 